\title{
Public Fundraising Campaign By Migrant Care For Liberation of Migrant Worker Satinah From Death Penalty In Saudi Arabia
}

Nadya Husein Zainuddin ${ }^{1}$, and AG Eka Wenats Wuryanta ${ }^{2}$

${ }^{1,2}$ Institut Komunikasi dan Bisnis LSPR, Jakarta, Indonesia

\begin{abstract}
Fundraising is not a common thing anymore. Especially if the fundraising is about the social campaign that will attract people's sympathy. Fundraising that Migrant Care did as one of the most successful public fundraising. Migrant Care had successfully collected 2,8 billion rupiahs in 2 weeks. This fundraising is for Satinah, an Indonesian migrant worker who was sentenced do death penalty because she was charged with murdering her employer. Migrant Care is non-governmental organization which protect the rights of Indonesian migrant workers stated their disappointment towards the Indonesian government that didn't help Satinah. Because of their disappointment, Migrant Care held the crowdfunding for Satinah's diyat. The method that used in this research is qualitative descriptive with interview and documentation with Carl Hovland's theory SMCR (source, message, channel and receiver).
\end{abstract}

Keywords: source; message; channel; crowdfunding; campaign

\section{Kampanye Penggalangan Dana Publik Migrant Care Untuk Pembebasan Pekerja Migran Arab Satinah Dari Hukuman Mati Di Arab Saudi}

\begin{abstract}
ABSTRAK
Penggalangan dana memang lumrah terjadi. Apalagi jika penggalangan dana tersebut menyangkut hal-hal sosial yang menarik simpati masyarakat. Penggalangan dana yang dilakukan oleh Migrant Care merupakan salah satu penggalangan dana yang berhasil mengumpulkan sejumlah Rp 2,8 milyar hanya dalam kurun waktu 2 minggu. Pengumpulan dana ini untuk seorang Satinah, TKI asal Ungaran Jawa Tengah yang terkena kasus hukuman mati di Arab Saudi karena tidak sengaja membunuh majikannya. Migrant Care selaku lembaga swadaya masyarakat yang bergerak di bidang perlindungan buruh migran menyatakan kekecewaannya atas pemerintah Indonesia yang lambat dan enggan membantu diyat Satinah dengan mengadakan crowdfunding. Metode penelitian yang digunakan adalah pendekatan kualitatif deskriptif dengan wawancara dan dokumentasi serta menggunakan teori SMCR dari Carl Hovland.
\end{abstract}

Kata kunci: sumber; pesan; channel; penggalangan dana; kampanye

\section{INTRODUCTION}

There are many problems faced by Indonesian workers who are abroad. The salary offered as a migrant worker abroad is indeed tempting because the amount is quite large, but prospective 
Nadya Husein Zainuddin | Public Fundraising Campaign...

workers do not realize that there are many risks that must be borne as a migrant worker. Human rights violations continue to afflict and haunt Indonesian workers and migrant workers around the world. Many workers from Indonesia (TKI) have experienced torture in Asia such as Malaysia, Taiwan to Hong Kong. In this case, the state as a protective actor and labor inspector must ensure that no workers are discriminated against, whether through gender, race and religion, against migrant workers. States must also ensure that workers are protected both through the laws and constitutions of the countries where they work. "Labor migration is a phenomenon that concerns all regions of the world, however almost half (48.5 per cent) of migrant workers are concentrated in two broad regions: Northern America, and Northern, Southern and Western Europe. The Arab States have the highest proportion of migrant workers as a share of all workers with 35.6 per cent" (ILO, 2015).

Injustice, violence, and torture experienced by migrant workers do not only happen in Indonesia, this has become an international concern and issue raised by international organizations such as the United Nations, the ILO and the UNHCR. According to data from the 2016 Global Slavery Index by Rights Group of Walk Free Foundations, nearly 46 million people worldwide live as slaves, sex workers and laborers who are involved in debt and debt (Bacchi, 2016, para 2). The ILO notes that there are 20.9 million people worldwide who are victims of slavery cases, of which 18.7 million people are victims of forced labor that is exploited in the economic sector, both by the private sector and individuals (ILO, 2015).

Another two point two million people became forced slave laborers who worked improperly. While other additional data states that 4.5 million of them are victims of sex slavery and 14.2 million of them are victims of forced slavery (ILO, 2015). Whereas the ILO (International Labor Organization) states in convention number 181 that all migrant workers get protection from violence, discrimination, child labor, additional money and costs that are not stated in the previous employment agreement and their privacy is not respected.

Being a migrant worker has a big risk, we can see from the data provided by the ILO that migrant workers around the world are victims of injustice in their work. Although the data on torture and human rights violations against migrant workers is quite high and is entering a serious stage, working abroad remains a job that is in demand, let alone being an Indonesian worker. Interest in Indonesian workers (TKI) according to data on the placement of Formal and Informal TKI during 2011 to 2015 shows a changing trend.

In 2015 the number of TKI who were placed abroad was 275,736 TKI decreased drastically compared to 2014 which reached 429,872 TKI. While in 2013, the placement of TKI abroad was 512,168, in 2012 there were 494,609 TKI, the previous year (2011) 586,802 TKI (BNP2TKI, 2016). The decline in the rate of sending TKI abroad was influenced by the closure of the sending of TKI in the informal sector abroad by the government. The government should not stop sending workers from the informal sector abroad but ratify the ILO convention no. 189 on protection and decent work for domestic helpers, said the Executive Director of Migrant Care. Strict supervision is needed from the government in order to continue to monitor the development of Indonesian workers who try their luck abroad so that they get clear and firm 
legal protection (Fathiyah, 2015).

The data available within the government is not only that, based on data from the National Agency for the Placement and Protection of Indonesian Migrant Workers (BNP2TKI) during January to November 30, 2015, the number of Indonesian workers sent to the Middle East with Saudi Arabia was 41,311 people, Oman 17,158 people, United Arab Emirates 16,400 people, Qatar 7,380 people, Bahrain 4,985 people and Kuwait 1,608 people (Kusumawati, 2015). These data show that although the moratorium on closing Indonesian workers to the Middle East and Africa is closed, there are still many Indonesian workers who are interested and decide to work abroad.

Referring to Regulation Number 3 of 2013, that the protection of TKI is all efforts to protect their rights, starting from the delivery process to the process when the TKI will return from their home country of work (PP, 2013). For more optimal work, the government reforms the system that makes it easier for Indonesian workers who are abroad. The Indonesian government abolished the KTKLN (Overseas Manpower Card) (Cabinet Secretariat of the Republic of Indonesia, 2014, para 3). A system that is strong, authoritative and has relevant standards is a prerequisite for an effective and influential in the world of work according to Guy Ryder, Director General of the ILO at the opening of the ILC in Geneva, Switzerland. (Iqbal. 2016).

The definition of the workforce itself is anyone who is able to do work to produce goods or services to meet their own needs, as well as the needs of the community that are sourced and refer to Article 1 number 2 of Law no. 13 of 2003. Then according to Article 1 number 3 of Law no. 13 of 2003 labor and workers are every person who works receiving wages or other forms of remuneration. Then the definition of migrant worker when translated into Indonesian is migrant: a person who moves from one place to another, either still within the country or abroad. While the meaning of worker: is a person who works or has a job. In the end, the definition of a migrant worker is a person who works or has a livelihood through working within or outside the country, between cities and between countries, in order to create economic sustainability to fulfill daily needs within a certain period of time. Migrant workers originating from Indonesia are commonly referred to as Indonesian Migrant Workers (TKI). Working abroad as migrant workers or even as housemaids does not dampen the enthusiasm of Indonesian workers.

There are so many problems that lurk the departure of TKI abroad, light sentences to beheadings lurk the departure of prospective workers. The death penalty case that befell Indonesian workers did not just happen once, we can look back at the beheading cases received by Ruyati, Darsem and Wilfrida Soik. Ruyati, Wilfrida and Darsem are Indonesian migrant workers who received the death penalty abroad for violating the law. This repeated incident proves that the government has not improved the existing laws and regulations regarding the protection of Indonesian workers. According to Saleh Daulay, a PAN politician, Indonesian workers receive light sentences up to the death penalty, based on data from the Directorate. PWNI and BHI, the Ministry of Foreign Affairs as of October 10, 2016, it was stated that 
Nadya Husein Zainuddin | Public Fundraising Campaign...

Malaysia was the country that imposed the most severe sanctions on TKI. A total of 136 cases, with 95 cases of narcotics, 37 cases of murder, 3 cases of kidnapping, and 1 case of firearm trafficking. Another case in Saudi Arabia, the total death penalty handed down to Indonesian migrant workers was 25 cases, with details of murder 12 cases, witchcraft 5 cases, and adultery 8 cases (RMOL.co. 2016).

The murder case this time also happened to Satinah. Satinah is a migrant worker from Ungaran, Central Java who went to Saudi Arabia to become a housemaid. She went to Saudi Arabia for the first time to become a housemaid in 2004. Then Satinah left for the second time to Saudi Arabia with the aim of earning money for her old age in 2007. Satinah finally committed the murder on June 17, 2007. On that day, Satinah's employer, Nura Al Gharib, suddenly came to Satinah who was cooking in the kitchen, banged her head against the wall and shouted at Satinah. Trying to defend herself, Satinah took the bread mill that was on the table beside her and hit her employer's neck until he fell and died.

Satinah then fled with her employer's money amounting to 37,970 Riyal or 139 million Rupiah (Wulandari. 2015). Not long after Satinah's departure from her employer's house she was arrested by the Buraidah police and imprisoned in Al Gassem Province. Satinah was named a suspect in premeditated murder and robbery for killing and escaping her employer's money. Satinah was sentenced to the Hadd Ghillah (premeditated murder so that only Allah can forgive). After two years of undergoing the trial, Satinah was not provided with a lawyer and was not accompanied at all, "the government doesn't know anything at all”, said Anis Hidayah as chairman of the Migrant Care management. However, in 2009 Satinah's sentence was reduced to a Qishas punishment (a life sentence for life or giving the victim's family the right to ask for the death penalty or pardon her). In the end, the victim's family forgave Satinah and replaced her with a diyat (blood money) of 10 million riyals and ended in negotiations that resulted in a final nominal of 7 million riyals or 21 billion rupiah (DetikNews, 2014, para. 8). The government's slow handling of things like this made Migrant Care raise public funds to provide assistance to Satinah to be free from the death penalty.

Migrant Care as a non-governmental organization (NGO) also encourages, strengthens and handles cases suffered by TKI directly. With the many suffering experienced by TKI who are abroad Migrant Care is present as a social movement to realize global justice for migrant workers (migrantcare.net. 2016). The public's concern for contributing to Satinah was so great that 3 billion rupiah was collected in less than a month (Tempo. 2014) for the cost of releasing Satinah. The fundraising done by Migrant Care for Satinah involves the public. This process can be categorized as voluntary fundraising or commonly referred to as crowdfunding. Crowdfunding is not a new thing that happens in this modern era, but crowdfunding has been around for a long time. Crowdfunding in this modern era uses the media as an intermediary between fundraisers and donors of funds, but in the same concept, mass fundraising has occurred since $3000 \mathrm{BC}$.

1876 can be called the year where the modern era of crowdfunding began. This year the great icon of the United States \& New York City, the Statue of Liberty raised funds to finance the 
construction of this monument. The citizens of France pay for the monument while the citizens of the United States pay for the plinth or foundation. These residents raise funds by holding performances such as theatre, auctions of art goods to public meetings to get the funds they need. Along with increasingly sophisticated technology, delivering technology-based crowdfunding. Crowdfunding that uses internet technology is crowdfunding through a website or social web, which is better known as "web .0" or "web 1.0" where all the information needed can be received. The website also helps very quickly and easily if the needy can persuade people who donate to spread the word about their crowdfunding to others with the help of social networks. However, in its development, crowdfunding is not always involved in business funding or business-related matters. But crowdfunding can also help answer emergency social needs.

The concept and term crowdfunding originally emerged as crowdsourcing which is defined as a process of outsourcing work to individuals, crowds of people, and relying on their resources, assets and expertise via the internet (Hemer, 2011). Crowdfunding is a movement that uses new media to announce or voice their steps and reasons for raising funds. Usually crowdfunding raises funds due to the absence of an optimal movement from the government, causing the emergence of movements from the community itself and from non-governmental organizations. The fundraising movement for Satinah could be an example of the government's unpreparedness in dealing with emergencies abroad, even though it concerns the welfare of its own citizens. Fundraising for Satinah can be a solution to problems that arise from the slow performance of the government and state law enforcers.

\section{METHODS}

The research method used is a qualitative research method. Qualitative research method with a descriptive approach is the method used in this research. According to Creswell, qualitative research is the process of examining the understanding of social or problems faced by humans based on the construction of complex, holistic images, united by words, reporting detailed views of informants, and carried out in natural settings (Trijono, 2015). Meanwhile, according to Denzin and Lincoln, a qualitative research is research that is interpretive (using interpretation) which always involves many methods in interpreting the research problem (Mulyana, 2006). The purpose of qualitative research is to find an answer to a phenomenon or a question through the application of scientific procedures that are carried out systematically.

This study used qualitative data collection methods consisting of unplanned-unstructured interviews and literature study. The technique used in this study is a semi-structured interview where the main goal is to find problems more openly, where the parties invited to interview are asked for their opinions and ideas (Sugiyono, 2015). So that in this study the results of interviews can include the opinions of the informants so that the data is more complete and open. On this occasion, the main focus of this research is how the communication pattern owned by Migrant Care has succeeded in raising funds from the Indonesian people to donate the ransom money for the release of Satinah, an Indonesian worker who was a suspect in the murder and got the death penalty status in Saudi Arabia. 


\begin{tabular}{|c|c|c|}
\hline Research Object & Element & Evidence \\
\hline \multirow{4}{*}{$\begin{array}{l}\text { Communication pattern by } \\
\text { Migrant Care in } \\
\text { conducting } \\
\text { crowdfunding for Satinah }\end{array}$} & Source & $\begin{array}{l}\text { a. Intent to Persuade } \\
\text { b. Attractiveness of The Source } \\
\text { c. Similarity of Source and Receiver } \\
\text { d. Power of The Source } \\
\text { e. Credibility of The Source }\end{array}$ \\
\hline & Message & $\begin{array}{l}\text { a. } \text { Comprehensibility } \\
\text { b. Number of Arguments Used } \\
\text { c. Rewards Within The Message } \\
\text { d. Arousal and Reduction of Fear } \\
\text { e. One-sided/two-sided messages } \\
\text { f. Order of Message Presentation } \\
\text { g. Message Repetition } \\
\text { h. Style of Presentation }\end{array}$ \\
\hline & Channel & $\begin{array}{l}\text { a. Face-to-face Versus Mass Media } \\
\text { b. Channel Attributes }\end{array}$ \\
\hline & Receiver & $\begin{array}{ll}\text { a. } & \text { Intelligence } \\
\text { b. } & \text { Self-esteem } \\
\text { c. } & \text { Gender differences }\end{array}$ \\
\hline
\end{tabular}

Source: Researchers Notes

Researchers will also conduct a literature study which will then be used as secondary data. In this study, the researcher used a semi-structured interview method. Semi-structured interview is an interview technique which in the process of implementation is more free than the structured interview process (Sugiyono, 2015). In this research, literature study is then used as secondary data. In the data collection technique, triangulation is defined as a data collection technique that is a combination of various data collection techniques and existing sources (Sugiyono, 2015). In the triangulation technique, the researcher uses different data collection techniques to obtain data from the same source, this shows that the researcher collects data at the same time to test the credibility of the existing data.

\section{RESULT AND DISCUSSION}

Satinah, who has been proven guilty of killing her employer, argues that this incident was an act of accident and as an act of self-defense because she was mistreated by her employer (Wahono, 2015). Satinah's self-defense was made worse by the theft of money that she committed after killing her employer. Satinah was proven to have stolen her employer's 37,970 riyals or 119 million rupiah (Dewi, 2014). Because of this act of murder and theft, Satinah was sentenced to death (because) and could be freed from beheading if Satinah was willing to pay an apology (diyat) of 7 million riyals or 21 billion rupiah (Wahono, 2015). 
The Indonesian government did not respond to the ransom of 21 billion rupiah at first, so Migrant Care as a non-governmental organization working in the protection of migrant workers arose to help Satinah through public fundraising. The public fundraising conducted by Migrant Care succeeded in attracting community empathy to donate Satinah's diyat money. In this study, the message-learning approach is used as a tool to analyze how Migrant Care has managed to raise a very large amount of public funds in a very short time. Within 2 weeks, Migrant Care managed to raise 2.8 billion for the release of Satinah's diyat through this public fundraiser (Pujangga, 2014).

\section{Source Variables}

In his view, Carl Hovland views that the tendency of individuals is to forget who delivered the message if the message was delivered by a low-credibility source (untrusted sources) and only remember the messages that have been delivered but do not remember who ever delivered the message. sleeper effect (Rogers, 1994). The right source is the main key in carrying out persuasive communication, this is often stated by Hovland in his research. Where reliable sources produce messages that are easy to receive and remember, not only in terms of the message but also in terms of the subject who conveys the message (Rogers, 1994). This is what causes Migrant Care to get a positive response from the community towards their public fundraising campaign.

In raising public funds that Migrant Care does, they do not work alone but also collaborate with the Ambassador of Migrant Care, Melanie Subono. The public's interest and trust in Melanie made this public fundraising campaign a success. Melanie Subono's role in the entertainment world is no longer in doubt. Born to a famous musician in Indonesia, Adrie Subono, Melanie also became a singer despite her illness (KapanLagi, 2014). Not only singing, Melanie Subono is also often an environmental, health and human rights activist (Santosa, 2014). Executive Director of Migrant Care Anis Hidayah said that Melanie's concern, Melanie Subono, for human rights issues was seen when Melanie issued a petition protesting Maftuh Basyuni's statement regarding the rape case of Indonesian migrant workers (Ratomo, 2014). This is why Melanie was chosen to be the Anti-Slavery Ambassador at Migrant Care (Ichsan, 2014). Migrant Care and Melanie Subono's track record is rated as attractiveness of the source.

Not only that, but the track record of Migrant Care as a non-governmental organization that has been active in the protection of migrant workers since 2004 (Mampu.or.id, n/d) makes Migrant Care always involved in every case that occurs to workers. Indonesian migrants. Defending and fighting for the rights of migrant workers has become the mission of Migrant Care. So that in early 2015, Migrant Care received the Yap Thiam Hien Award 2014 for its merits in upholding human rights (Migrant Care Secretariat, 2015). So that the element of credibility of the source from Migrant Care has been proven.

The power of the source as the success achieved by Migrant Care is the result of their hard work against the injustices that often occur to migrant workers, not only that. The success achieved by Migrant Care in almost every case that occurs to migrant workers is also due to the perseverance of Migrant Care itself. Anis Hidayah as Executive Director of Migrant Care said in an interview with BBC Indonesia that they did not always achieve success, for example in the case of Indonesian Migrant Workers Ernawati who was often tortured by her employer. 
Nadya Husein Zainuddin | Public Fundraising Campaign...

Ernawati reported to Migrant Care and it was Migrant Care's job to ask for help from the Indonesian government, but because of the slow bureaucracy, Ernawati's life was not saved. The slow attitude of the Indonesian government is what makes Anis angry because this delay could lead to the loss of life (BBC Indonesia, 2012).

Migrant Care's involvement in the world of labor advocacy protection led Migrant Care to sign an MoU with the Ministry of Women's Empowerment in 2007 regarding a program for monitoring public services for female migrant workers at the special terminal for migrant workers (Terminal TKI) at Soekarno Hatta Airport (capable.or.id, n/d). In addition to this program, Migrant Care with the Indonesian government is also involved in various working groups organized by the Government of Indonesia and also the TIFA Foundation. Not only is Migrant Care involved in the protection of domestic migrant workers, but Migrant Care also maintains a relationship with the Ford Foundation and Cordaid which is a protection agency (capable.or.id, n/d). Because it is the main task of Migrant Care to protect migrant workers, in the case that happened to Satinah, Migrant Care insisted on protecting Satinah's life from the threat of the death penalty.

The failure due to the government's slow role in protecting migrant workers makes Migrant Care on this occasion involve the wider community in their public fundraising. Migrant Care's intention to persuade itself can be divided into two, namely in terms of micro and macro aspects. When viewed from a micro perspective, Migrant Care has a main goal, namely to get a very large and urgent diyat money in a small amount of time. But in the end Migrant Care managed to collect diyat money of 2.8 billion rupiah in just 2 weeks (Pujangga, 2014). Getting a large amount of money in a short period of time is an achievement in itself for Migrant Care. And if viewed from a macro perspective, Migrant Care wants to 'hit' the Indonesian government for its delay and reluctance in helping Satinah in this case. Migrant Care also expressed its disappointment with the Indonesian government in an interview with researchers some time ago. Wahyu Susilo as Executive Director of Migrant Care said: "Actually, this crowdfunding is a form of our disappointment (Migrant Care) towards the Indonesian government, which is reluctant to allocate its state budget for diyat, which can actually be a way out for Satinah to get out of the death penalty. Because in the judicial process it is no longer possible. The way out is outside the judiciary and one of the things that can open this space is diyat. The government argues that there will be many cases of injustice in the future, many people will be jealous, but we (Migrant Care) are of the opinion that this is the result of the government's lack of seriousness and the government's negligence in facing the death penalty. The reason we really want to encourage, apart from proving that if the government does not want to help, the community will intervene but we will also provide public awareness to the Indonesian people that there are still many problems experienced by migrant workers, one of which is the threat of the death penalty" (W. Susilo, primary data interview, 18 April 2017).

However, Migrant Care's expression of disappointment with the Indonesian government was denied by the Indonesian Ministry of Foreign Affairs (Kemenlu) for the protection of Indonesian citizens and BHI Arif Hidayat, who also handled the Satinah case. The Ministry of Foreign Affairs stated through interviews with researchers that:

"There are principles in providing protection. The protection provided is based on local law, international law and our national law. It means that our national law is at the back. What's 
the point? What happened to Satinah, we are dealing with the legal system/rule of law in other countries. Where we cannot interfere, cannot intervene, cannot carry out an intervention process against a legal process that occurs. In my opinion, the Government's efforts are something that should be done. But what the public doesn't know is that there are several Saudi legal systems, there are types of crimes where the intervention of even the Saudi King's intervention cannot be there. In the case that happened to Satinah, the Saudi government could not intervene. Our government cannot intervene. It is the family of the victim who can intervene or change the claim. If the victim's family provides forgiveness, whether free pardon or forgiveness through diyat is not the decision of the governments of the two countries. But indeed the legal system in Saudi states that everything depends on the victim's family. In this case the family of the victim Satinah gave forgiveness, but demanded diyat money (diyat money is blood money). That's what happened. From a legal point of view, in terms of the material indictments that occurred before two years ago (two years of Satinah's sentence running without any legal assistance from the Government of Indonesia) will not change. Because everything is dependent on the evidence. The material evidence already exists from the case. Because of what? What I know from the legal system is that if someone doesn't acknowledge the minutes of the previous examination, that's fine. Is it assuming that he was tortured, whether at that time he was not accompanied by a lawyer, it can still be done. I see that the case or the sentence imposed on Satinah is a type of law that only the victim's family can forgive. There is not the slightest room for the Government or the King to intervene. It all depends on the victim's family. But what I see from the point of view of the material indictment or punishment there will be no change, according to friends in the known NGOs, is, if this is accompanied or not, look at the legal material, please. The legal material is a must see. What is the material for this crime, what is the threat, how is it handled. The only strategy is forgiveness from the victim's family. Second, the material, the material evidence is all clear. No scarves, or anything everything was clear. Third, the person concerned also confessed. I said earlier, if he wanted to refuse the news, he could. I'm sure our lawyer has made an offer, whether to refuse or not. But again, it is important for the public to know that the type or material or nature of the law in Saudi is very different from the law in Indonesia. Very, very different." (A. Hidayat, primary data interview, 29 May 2017).

If you draw conclusions from the statements of both parties, it is clear that the case that happened to Satinah is a complex case. Where the Indonesian government cannot provide protection for Indonesian citizens who are involved in legal cases abroad because the laws of a country cannot be intervened. The involvement of state leaders in the Satinah case could not free Satinah from the death penalty. Only the victim's family can apologize so that Satinah is not sentenced to death. In this case, the victim's family wants Satinah to pay diyat of 21 billion rupiah to be free from the death penalty. But of course this is not the responsibility of the Indonesian government, which is the reason the Indonesian government seems reluctant to help in this case. Satinah was right to kill even though it was in self-defense and it should be remembered that Satinah was proven and admitted to stealing her employer's money. According to the statement of the Ministry of Foreign Affairs on the results of interviews with researchers that: "The government doesn't directly help diyat for Satinah? Initially reluctant to help diyat, the government is not responsible according to the laws and regulations. Because the Government is not the one who signed the document signed by Satinah. What has been paid by the Government by the previous case of Darsem. It's actually a case that we think has been 
Nadya Husein Zainuddin | Public Fundraising Campaign...

something of an exaggeration. Because it is no longer part of the Government to take over. The task of the government is to ensure (again) the Indonesian citizen gets a fair trial, his rights are guaranteed, not his freedom” (A. Hidayat, primary data interview, 29 May 2017).

Satinah is not the first person to receive assistance either through public fundraising or even official assistance from the Indonesian government. A similar case in 2011 also happened to Darsem, who was sentenced to death in Saudi Arabia for killing his employer. Darsem committed the murder purely out of self-defense (JPNN, 2011). Because of this murder, Darsem was sentenced to death and received an apology with a diyat of 2 million riyals or 4.7 billion rupiah. At first the TV One television station held a public fundraising campaign for Darsem's release and managed to raise 1.2 billion rupiah through 'Koin Untuk Darsem' (DetikNews, 2011). TV One said that this public fundraising was an inspiration from the previously held public fundraising, namely 'Koin Untuk Prita' (DetikNews, 2011). But in the end the money from this public fundraising was not used successfully, because the Indonesian government through the Ministry of Foreign Affairs said that the diyat for Darsem was the responsibility of the government (DetikNews, 2011). However, the money from the donations from TV One viewers was ultimately donated to Darsem personally and has been fully handed over to Darsem's needs (DetikNews, 2011).

According to news circulating, Darsem used the proceeds from the 1.2 billion donation for a spree (JPNN, 2011). Darsem reportedly bought a house, jewelry, and even rice fields from the money from the public fund donation (JPNN, 2011). This makes many parties feel uneasy, because the donation money should be for the release of diyat not for the tertiary needs of Darsem. However, the public fundraising for Darsem did not turn out to be a lesson for public fundraising for Satinah. The similarity of the source between the Darsem and Satinah cases has succeeded in attracting public attention related to this public fundraising. The enthusiasm of the Indonesian people to donate for the release of the death convict Satinah who became a migrant worker in Saudi Arabia has actually increased. This can be seen from the nominal earned by Migrant Care regardless of Satinah's actual legal status. Indonesian people still see a similar case as a case that claimed human rights, they do not see this from a legal standpoint that ensnares the subject.

\section{Message Variables}

Messages about Satinah's case have been circulating on social media and online and conventional news since early 2014. Migrant Care is the only NGO that voices the importance of saving the price of one life. \#SaveSatinah is a hash tag spread through Twitter social media that expresses support for the release of the death convict Satinah. Where the artist Melanie Subono often voices her support for Satinah through her Twitter social media. In addition to expressing her support for Satinah, Melanie also often mentions why the Indonesian government is reluctant to help with Satinah's case. However, this disappointment is not only due to negligence in assisting legal cases and also negligence due to the slow response to assistance from Migrant Care but the government's reluctance in allocating the State Budget for the release of Satinah. The main focus taken by Migrant Care does not question whether Satinah is actually stealing or not, killing intentionally or actually defending herself. The focus of Migrant Care is on the government's negligence in the legal assistance process during the trial period and on the process of releasing Satinah's very large diyat. 
When compared with the view from the government's point of view, according to the results of interviews with the Ministry of Foreign Affairs, researchers say that: "You see, a person according to Saudi customs once someone is proven to have hit, what people know, that person will be wrong, will be arrested by the police. The point is what, if he has committed a violent act, that someone he will be arrested, and can be given a severe punishment. People don't see why he hits, this is what happened with Satinah too. Satinah's confession, she was treated harshly. Experiencing physical violence. Because he couldn't stand it, he took revenge. The retaliation resulted in fatal consequences for the female employer, who died immediately. People see it's fatal. But of course our lawyers and our representatives have conveyed all the mitigating factors, including why Satinah did that. I'm sure it's been done. This is what I think, in my estimation, there is a real shift that maybe the victim's family really doesn't want to sue for diyat to want to sue for diyat. Remember, the family has a right. He has the right not to forgive or he has the right to forgive without anything or he has the right to forgive with diyat. I believe there has been a shift in the position of the victim's family. I believe it is because our government has succeeded in revealing the factors why Satinah did that. So not only. If it's just for no reason, I'm sure the victim's family will not forgive and will not ask for diyat. Because diyat is a form of forgiveness. But yes, Satinah is accused of stealing. Yes, maybe because of panic or something." (A. Hidayat, primary data interview, 29 May 2017).

The Indonesian government asserts that this is back to the legal regulations in force in Saudi Arabia. That a life is very valuable, even though Satinah said that her actions were purely selfdefense. Satinah's case was complicated by the fact that she stole her employer's money. Of course this is a must for Migrant Care as an institution that defends and fights for Satinah's case to be published. That Migrant Care defends someone who is true is proven to have stolen. It is really unfortunate that the focus of Migrant Care is only on advocating for Satinah's defense law not on why Satinah was punished. Migrant Care's transparency regarding Satinah's legal case is not clearly described. Comprehensibility in this case is not clear enough. Cornering the Indonesian government as an institution that failed to protect its migrant workers.

This was stated by Melanie Subono in Tempo's online news that SBY as President of Indonesia was like a tulalit as if he had already been deaf in this case (Hadriani, 2014). Cornering the Indonesian government but not revealing the facts, makes Migrant Care attract the empathy of the Indonesian people not with lies but with facts that are not revealed. Imagining the feelings of others is probably one of the most effective words in generating empathy. If we see and accept the behavior and habits of others, it will be easier for us to understand and accept diversity (Thomas, 2010). Migrant Care uses this excuse to convey to the Indonesian people that we are also responsible for what happened to Satinah, because this is a humanitarian matter.

Humanitarian issues make rewards within the message not directly to the donor, but the effect is on the person involved in the case. The fear of losing Satinah as a migrant worker is also felt by the Indonesian people. According to Anis Hidayah, this public fundraising action is important to emphasize to the Indonesian government that one life must be respected (Ruqoyah, 2014). This sentence is often said to make people empathize with Satinah. Arousal and fear reduction can grab people's attention (Rogers, 1994). According to Hovland, one of the keys to persuasion is to focus on the 'fear' or fear that is caused if something we are trying 
Nadya Husein Zainuddin | Public Fundraising Campaign...

to persuade doesn't happen. However, if the fear caused is too great it will not be effective in persuading others. On the other hand, if the fear is 'moderate', it will be more effective in its use (Rogers, 1994). Migrant Care's effectiveness in persuading the Indonesian people is also due to the use of a two-sided message, where Migrant Care often compares the Indonesian government's treatment of the case that happened to Satinah. Where the government is slow in responding to the legal case that happened to Satinah.

It can be concluded from the results of interviews with researchers on the case of Satinah's death penalty, neither the Indonesian government nor the Saudi Arabian government could intervene regarding the death sentence that ensnared Satinah. No matter how enthusiastic the Indonesian people are in helping Satinah, the death penalty will continue if Satinah cannot pay the diyat according to the agreement. The diyat money that Migrant Care finally managed to collect amounting to 2.8 billion rupiah in a period of 2 weeks was also the result of an order of message presentation where the message was successfully conveyed and received by Migrant Care to the Indonesian people well. Messages that are successfully conveyed to many people are of course also thanks to repetition (message repetition) or repetition of the message. Repetition or repetition of messages in the Satinah case does not only occur in online media and news on television, but there are many people who sympathize with Satinah through social media Twitter with \#SaveSatinah. Not only the public sympathized, but at the beginning of this case Melanie Soebono and Migrant Care spoke through their Twitter accounts. So the style of presentation of this message is through social media and conventional which is dominated by social media.

\section{Channel Variables}

Face-to-face versus mass media in delivering messages is one of the important points where the use of channels plays a role so that the message is conveyed effectively and can be well received by the receiver. In order for messages to be conveyed properly and effectively, many parties who want to spread messages no longer use the face-to-face method but use mass media. In addition to spreading messages more quickly and evenly, mass media is also a key institution in people's lives (Biagi, 2017). Mass media also influences our culture, buying habits and political views (Biagi, 2017). There are 3 important concepts in the view of mass media according to Shiley Biagi that affect the lives of Americans, namely:

a. Mass media is a business with profit as its main goal

b. Technological developments are changing how mass media is delivered and consumed c. Mass media reflects and influences politics, social life and culture

There are so many and important aspects of mass media that make mass media an effective channel for campaigning. The decision taken by Migrant Care to campaign for its public fundraising for Satinah through mass media was the right decision. The rapid spread of news, low costs and media that are always in the midst of society make mass media very effective (Biagi, 2017). The mass media used by Migrant Care in spreading the news about Satinah's death was not only through conventional media, but Migrant Care also did it on social media. This was revealed in an interview with Migrant Care: "We do this crowdfunding in various ways, what we can do is through social media. Because Migrant Care itself prioritizes Social Media as an advocacy tool, we also invite several activists and celebrities who I think are active in this context, Melanie Soebono. Even in this context, we were able to communicate 
with the Governor of Central Java, Ganjar Pranowo, who also welcomed the proposal for crowdfunding. He even suggested activities there and I also remember that time Melanie Soebono made a fund night at Wisma Peace in Semarang and got several things like that. Apart from crowdfunding, we also conducted a public support campaign, when we came to the City Hall when we were still a presidential candidate for Jokowi as Governor of Jakarta. Then we also ask for support from him. In addition, at that time we also used the www.change.org platform to make support for the government at that time to provide or allocate diyat for Satinah".

Figure 1 Social Mediq Campaign of Satinah's Crowdfunding
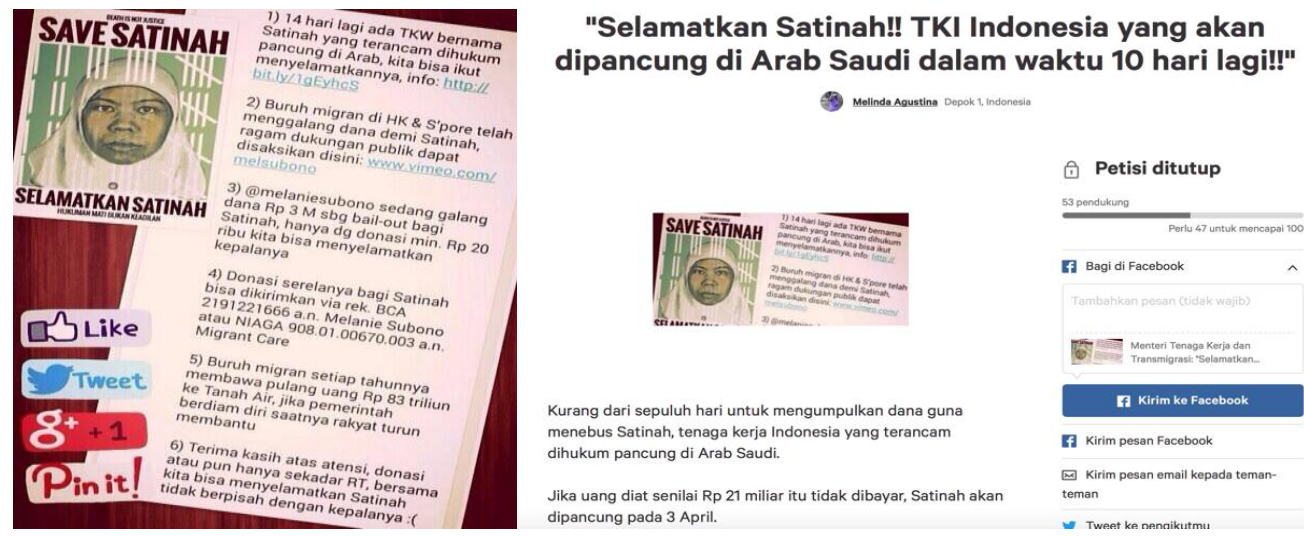

Source: Social Media Capture

By prioritizing social media such as Twitter to spread content about the Satinah case, Migrant Care also created the hashtag \#SaveSatinah to support Satinah. Not only supporting Satinah through social media, Migrant Care also conducted a support campaign for Satinah through the website www.change.org. Satinah's supporters can sign this online petition via the change.org website so that Satinah does not get beheaded. So much support for Satinah circulated in the mass media. Migrant Care's success in acquitting Satinah's case from the beheading of course cannot be separated from a good communication strategy.

\section{Receiver Variables}

When the dissemination of information and the message contains things that are persuasive, of course, it takes the target audience or receiver of information with the right and right characteristics. Intelligence, self-esteem and gender differences must be considered so that the intended message can be received according to the target. In this case Migrant Care in its public fundraising action of course has its own target audience, this was revealed in interviews conducted between researchers and Migrant Care: "Well, the target audience for Migrant Care is the social media users at first. Because I think that in 2013-2014, our social media was booming, many people took advantage of it, especially at that time when public campaigns, both for the governor election and the presidential election, used social media. The consideration is that we want to encourage them to become click activism. So if people use social media, they feel that they care, feel that they have supported the case or supported the resolution of the case or solidarity by clicking like or retweeting or something. Not taking direct 
Nadya Husein Zainuddin | Public Fundraising Campaign...

action, what we encourage is that there is also direct action. For example, donating or they participate in the actions we use" (Wahyu Susilo, Primary Data Interview, 18 April 2017)

Migrant Care realizes that its public fundraising action will not be achieved if click activism is not carried out properly. Click activism is the use of social media and other online platforms to promote a cause (Clicktivist, n/d). The use of online petitions, support through various social media is an appropriate and efficient step if you want to convey a message in a short time. According to the results of interviews with researchers and Migrant Care, it is said that in fact the main recipient of this fundraising is the Indonesian government. "I think there was a response from the government at that time, the local government for example at that time Pak Ganjar positively welcomed our support, even he (because at that time he was from the opposition party he became governor) the government was also from other parties I think he was also the local government participate (because of pressure) from our public campaign, he also pressured the central government to make concrete efforts from Satinah. I think at that time there was a debate among the central government, whether to allocate government money either from the APBN or non-budgetary funds for Satinah or not".

Because the government's response was slow and seemed reluctant to contribute to the release of Satinah, Migrant Care 'pressed' the Indonesian government by holding this public fundraising event. The communication strategy launched by Migrant Care turned out to be fruitful, funds were collected quickly and in large quantities. The public's sympathy rolled when they knew that the Indonesian government was slow in responding to this, even though punctuality and expertise in inter-state diplomacy were very much needed in an urgent situation like this. The dominant factor of this success is Migrant Care's accuracy in using communication platforms and delivering messages to the wider community. Messages regarding the news of how suffering Satinah is in Saudi Arabia who are waiting for help from Indonesia to the reluctance of the Indonesian government to help, the facts about the murder that Satinah experienced are an attempt to defend herself, do not reveal the facts about Satinah's legal status by Migrant Care so that not many people know that Satinah actually stole her employer's money, efficient use of social media, spread quickly to low cost made this fundraising great success.

\section{CONCLUSION}

Satinah is an Indonesian worker who started working in Saudi Arabia in 2004. In 2007 Satinah who worked for Nura Al Gharib often received unpleasant treatment from her employer. Satinah's employer on June 17, 2007 suddenly came to Satinah who was cooking in the kitchen and immediately banged Satinah's head against the wall and shouted at Satinah. Feeling threatened, Satinah took the bread mill that was on the table beside her and hit Nura's neck so that she fell and died instantly. Then Satinah ran away and took her employer's money worth 37,970 riyals or 139 million rupiah. Shortly after his disappearance, Satinah was arrested by the Buraidah police in Al Gassem Province, Saudi Arabia. Since then, Satinah has been named a suspect in premeditated murder and robbery and has often been on trial. Because for several years Satinah has been on trial without a legal representative from the Republic of Indonesia, 
Migrant Care as a non-governmental organization engaged in the protection of migrant workers, spoke up.

Migrant Care said that the Indonesian government was negligent in handling the case of migrant worker Satinah so that the death penalty could be imposed. Migrant Care also said that the Indonesian government did not assist Satinah in legal aid matters, so Satinah often faced trials without legal assistance. It was unfair for Satinah to serve her sentence and trial without a lawyer during these times. However, according to Arif Hidayat as KASUBDIT Protection for Indonesian Citizens, he said that in this case the Indonesian government was the last resort in handling Satinah's case. Instead he said that the PJTKI, Satinah's employer and her Satinah should be the ones most responsible for what happened in this case. Arif also denied that the Indonesian government did not provide legal assistance to the Satinah case. He reiterated that a fair trial against Satinah had been obtained by him, but the matter that Satinah's diyat was the responsibility of the Indonesian government was wrong. It is said that the Indonesian government did not participate in signing the work contracts carried out by the PJTKI, Satinah or Satinah's employer herself so that this does not make this the responsibility of the central government.

But in the end, Migrant Care held a public fundraising or crowdfunding that succeeded in attracting sympathy and empathy from the Indonesian people. With the source, message, channel and receiver (SMCR) theory, Migrant Care can carry out this crowdfunding well. Assisted by the ambassador from Migrant Care Melanie Subono as a credible source, a message containing messages about Satinah's suffering, the channel used was very effective, namely social media, and Indonesian community receivers generated funds of 2.8 billion rupiah in just 2 years. week. A structured and precise communication pattern made Migrant Care successful in raising funds for Satinah's diyat.

\section{REFERENCES}

Abdillah, F. and Danial, E. (n.d). Crowdfunding: Demokratisasi Akses Keuangan dalam Mendukung Aksi Sosial Mahasiswa. Diperoleh dari https://www.academia.edu/16036806/crowdfunding_demokratisasi_akses_keuangan_d alam_mendukung_aksi_sosial_mahasiswa

Afrizal. (2016). Metode Penelitian Kualitatif: Sebuah Upaya Mendukung Penggunaan Penelitian Kualitatif dalam Berbagai Disiplin Ilmu. Jakarta, Indonesia: PT. Rajagrafindo Persada.

Arubone. (2016, October, 12). DPR Tuntut Pemerintah Bersungguh Lindungi $161 \mathrm{TKi}$ Terancam Dihukum Mati. Diperoleh dari http://politik.rmol.co/read/2016/10/12/264095/dpr-tuntut-pemerintah-\%20bersungguhlindungi-161-tki-terancam-dihukum-mati-

Bacchi, U. (2016, November, 14)). New U.N. Role Needed to Fight Human Trafficking in Conflict: Experts Yahoo News. Diperoleh dari https://www.yahoo.com/news/u-n-roleneeded-fight-human-trafficking-conflict-010901538.html

BBC Indonesia. (2011, March, 6). Upaya Membebaskan Darsem dari Hukuman Mati. Diperoleh dari 
Nadya Husein Zainuddin | Public Fundraising Campaign...

http://www.bbc.com/indonesia/berita_indonesia/2011/03/110306_tkw.shtml

BBC Indonesia. (2012, May, 31). Anis Hidayah Terlibat Total di TKI. Diperoleh dari http://www.bbc.com/indonesia/multimedia/2012/05/120531_tokohanis.shtml

Betsil, M, M. (2008). NGO Diplomacy. The Influence of Nongovermental Organizations in International Environmental Negotiations. New York, United States of America: The MIT Press, Massachusetts

Biagi, S. (2017). An Introduction to Mass Media (Twelfth Edition). Cengage Learning. Boston, United States of America. Diperoleh dari https://books.google.co.id/books? $\mathrm{id}=\mathrm{gMsaCgAAQBAJ} \&$ printsec $=$ frontcover\&dq=mass + media\&hl=en\&sa $=X \&$ redir_esc $=y \# v=$ onepage $\& \mathrm{q}=$ mass $\% 20$ media $\& \mathrm{f}=$ false

BNP2TKI (Badan Nasional Penempatan dan Perlindungan Tenaga Kerja Indonesia), Admin, (2016), Diperoleh dari

http://www.bnp2tki.go.id/read/10950/BNP2TKI-:-Prediksi-RemitansiTKI-tahun2015-Tercapai

Briones, L. (2009). Empowering Migrant Women Why Agency and Rights are not Enough. Surrey, England: Ashgate Publishing Company.

Clicktivist. (n/d). Clicktivist - Digital Campaign, One Click at A Time. Diperoleh dari website: Clicktivist http://www.clicktivist.org/what-is-clicktivism/

Coffman, J. (2002). Public Communication Campaign Evaluation (An Evironmental Scan of Challenges, Criticisms, Practices and Opportunities). Diperoleh dari http://www.hfrp.org/evaluation/publications-resources/public-communicationcampaign-evaluation-an-environmental-scan-of-challenges-criticisms-practice-andopportunities

Detik News. (2014, March, 26). Ini Penyebab Satinah Dihukum Pancung. Diperoleh dari http://news.detik.com/berita/2537126/ini-penyebab-satinah-dihukum-pancung

DetikNews. (2014, August, 2011). TV One Berharap Darsem Gunakan Sumbangan Rp 1,2 M dengan Bijak. Diperoleh dari http://news.detik.com/berita/1697712/tvone-berharapdarsem-gunakan-uang-sumbangan-rp-12-m-dengan-bijak

Dewi, S. (2014, April, 3). Negosiasi Diyat Alot, Bagaimana Nasib Satinah. Diperoleh dari http://dunia.news.viva.co.id/news/read/493793-negosiasi-diyat-alot-bagaimana-nasibsatinah

Danmayr, F. (2014). Archetypes of Crowdfunding Platforms (A Multidimentional Comparison). Steyr, Austria : Springer Gabler.

Drenser, S. (2014). Crowdfunding: A Guide to Raising Capital on the Internet. New Jersey, United States of America: John Wiley \& Sons, Inc.

Fathiyah. (2015, February, 25). Pemerintah Akan Hentikan Pengiriman TKI Sektor Informal Secara Bertahap. Diperoleh dari http://www.voaindonesia.com/a/pemerintah-akanhentikan-pengiriman-tki-sektor-informal-secara bertahap/2657994.html

Gea, F. (n.d). Crowdfunding: Gerakan Baru Kegotongroyongan di Indonesia (Tinjauan Evolusi Gerakan Aksi Kolektif Dalam Media Baru). Diperoleh dari https://www.academia.edu/27878870/CROWDFUNDING_GERAKAN_BARU_KEG OTONGROYONGAN_DI_INDONESIA_TINJAUAN_EVOLUSI_GERAKAN_AKSI 
_KOLEKTIF_DALAM_MEDIA_BARU_

Google Image. (2016). Teknik Analisis Data Miles \& Huberman. Diperoleh dari https://www.google.co.id/search?q=teknik+analisis+data+kualitatif\&es $\mathrm{pv}=2 \& \mathrm{biw}=1276 \& \mathrm{bih}=680 \&$ source $=1 \mathrm{nms} \&$ tbm $=$ isch $\& \mathrm{sa}=\mathrm{X} \& \mathrm{ved}=0 \mathrm{ahU}$ KEwiG17u377vRAhUHPo8KHVVaBwQQ_AUIBygC\#tbm=isch\&q=tekn $\mathrm{ik}+$ analisis+data+miles+dan+huberman\&imgrc $=5$ ebhJzuLOL8G9M\%3 A

Gunawan, I. (2015). Metode Penelitian Kualitatif: Teori dan Praktik. Jakarta, Indonesia: PT. Bumi Aksara.

Hadriani, P. (2014, April, 2). Kasus Satinah, Melanie Subono: SBY Tulalit. Diperoleh dari https://m.tempo.co/read/news/2014/04/02/219567291/kasus-satinah-melanie-subonosby-tulalit

Husmiati, PhD. (2015). Perlindungan Sosial Pekerja Migran Bermasalah Melalui Rumah Perlindungan Trauma Center - Kementrian Sosial R.I. Jakarta Timur: P3KS Press. Diperoleh dari http://webcache.googleusercontent.com/search?q=cache:http://puslit.k emsos.go.id/download/365

Husni, Lalu. (n.d). Perlindungan Hukum Terhadap Tenaga Kerja Indonesia di Luar Negeri. Diperoleh dari https://journal.ugm.ac.id/jmh/article/view/16206/10752

International Labor Organization (ILO. n.d.) "International Convention on the Protection of the Rights of All Migrant Workers and Members to Their Families." Diperoleh dari website ILO: http://ohchr.org/EN/ProfessionalInterest/Pages/CMW.aspx

International Labour Organization (ILO). (2015). "ILO Global Estimates on Migrant Workers." Geneva, Switzerland. Diperoleh dari website ILO: http://www.ilo.org/global/topics/labour-migration/publications/WCMS_436343/lang-en/index.htm

International Labor Organization (ILO). (n.d). "International Labour Standards on Forced Labour.” Diperoleh dari website ILO: http://ilo.org/global/standards/subjects-coveredby-international- labour-standards/forced-labour/lang--en/index.htm\#P23_4987

International Labor Organization (ILO. (2015). Protection of Migrant Workers in The Recruitment and Thrid Party Employment Process. Thailand : International Organization Labor Publication Data.

Ichsan, N. (2014, January, 30). Melanie Subono Duta Anti Perbudakan Migrant Care. Diperoleh dari http://www.tribunnews.com/images/seleb/view/996732/melanie-subonoduta-anti-perbudakan-migrant-car

Iqbal. (2016, June, 7), Besok, Menaker Pidato di Hadapan Pimpinan Negara Anggota ILO. Diperoleh dari http://ekbis.rmol.co/read/2016/06/07/249070/Besok,MenakerPidato- Di-Hadapan-Pimpinan-Negara-Anggota-ILO-

JPNN. (2011, August, 10). Kisah Darsem, si TKI Lolos Pancung, Setelah Dapat Sumbangan Miliaran Rupiah. Diperoleh dari http://www.jpnn.com/news/kisah-darsem-si-tki-lolospancung-setelah-dapat-sumbangan-miliaran-rupiah

KapanLagi. (2012, Juanuary, 27). Melanie Subono Akan Terus Nyanyi Walau Sakit. 
Nadya Husein Zainuddin | Public Fundraising Campaign...

Diperoleh dari https://www.kapanlagi.com/showbiz/selebriti/melanie-subono-akanterus-bernyanyi-walau-sakit.html

Kartika. (2014, December, 30). Kenapa TKI Bermasalah di Luar Negeri. Diperoleh dari $\mathrm{http} / / / \mathrm{www}$.antarasumsel.com/berita/291317/kenapa-tki-bermasalah di- luar-negeri

Kusumawardhani, A. (2017, February, 19). Moratorium Terbukti Tak Efektif Lindungi TKI. Diperoleh Dari http://industri.bisnis.com/read/20170219/12/629950/moratoriumterbukti-tak-efektif-lindungi-tki

Kusumawati. (2015, July, 7). Moratorium TKI ke Timur Tengah Dinilai Kepanikan Pemerinah. Diperoleh dari https://www.cnnindonesia.com/nasional/20150507200500-20-51956/moratorium-tkike-timur-tengah-dinilai-kepanikan-pemerintah/

Liputan 6. (2011, March, 8). Galang Dana untuk TKI Darsem. Diperoleh dari http://news.liputan6.com/read/323375/galang-dana-untuk-tki-darsem

Mampu.or.id (n/d). Migrant Care Profil. Diperoleh dari http://www.mampu.or.id/id/partner/migrant-care

Michico, R, N. (2016, September, 9). Migrant Care Adakan Kerjasama dengan Pemerintahan Desa untuk Perlindungan TKI. Diperoleh dari http://news.detik.com/berita/d3294810/migrant-care-adakankerjasama-dengan-pemerintahan-desa-untukperlindungan-tki

MigrantCare, (2016). Sejarah. Diperoleh dari website Migrant Care: http://migrantcare.net/profil/sejarah/

Migrant Care. (2016). Visi \& Misi. Diperoleh dari website Migrant Care: http://migrantcare.net/profil/visi-misi/

Mulyana, D. (2008). Penelitian Komunikasi Kualitatif. Yogyakarta, Indonesia: PT. LKIS Pelangi Aksara.

Patilima, H. (2013). Metode Penelitian Kualitatif. Bandung, Indonesia : $\quad$ ALFABETA Bandung.

Pujangga, F, R. (2014). Melanie Subono Bawa Bantuan Rp. 2,8 Miliar untuk Satinah. Diperoleh dari http://jateng.tribunnews.com/2014/04/02/melanie-soebono-bawa bantuan-rp-28-miliar-untuk-satinah

Pembayun, E, L. (2013). One Stop Qualitative Research Methodology in Communicaton. Jakarta, Indonesia: Lentera Ilmu Cendikia.

Peraturan Pemerintah Republik Indonesia. (2013). Diperoleh dari http://pih.kemlu.go.id/files/2013_pp_no.3_Tentang_PERLINDUNGAN_TENAGA_K ERJA_INDONESIA_DI_LUAR_NEGERI.pdf

Rahman, A. (2014, March, 27). Charlie Setia Band, Galang Dana untuk Satinah di Kediri Diperoleh dari http://hiburan.metrotvnews.com/read/2014/03/27/223794/charlie-setia band-galang-dana-untuk-satinah-di-kediri

Ratomo, T, U. (2014, January, 29). Melanie Subono Terpilih Menjadi Duta Anti Perbudakan. Diperoleh dari http://www.antaranews.com/berita/416567/melanie-subono-terpilih-jadiduta-anti-perbudakan 
Rmol.co. (2016, October, 12). DPR Tuntut Pemerintah Bersungguh Lindungi 161 TKI Terancam Dihukum Mati. Diperoleh dari http://rmol.co/dpr/read/2016/10/12/264095/DPR-Tuntut-Pemerintah-BersungguhLindungi-161-TKI-Terancam-Dihukum-Mati-

Rogers, M, E. (1994). A History of Communication Study - A Biographical Approach. New York, United States of America: The Free Press - A Division of Macmillan, Inc.

Ruqoyah, S. (2014, April, 1). Aksi Seribu Lilin Bebaskan Satinah dari Hukuman Pancung. Diperoleh dari http://nasional.news.viva.co.id/news/read/493297-aksi-seribu-lilin bebaskan-satinah-dari-hukuman-pancung

Santosa, W, L. (2014, January, 29). Melanie Subono Terpilih Jadi Duta Anti Perbudakan. Diperoleh dari http://www.antaranews.com/berita/416567/melanie-subono-terpilih-jadiduta-anti-perbudakan

Sekertariat Migrant Care. (2015). Terus Membela Buruh Migran. Diperoleh dari website Migrant Care: http://migrantcare.net/terus-membela- buruh-migran/

Sekertariat Kabinet Republik Indonesia. (2015). Video Conference Dengan TKI di Sejumlah Negara, Presiden Jokowi Hapus KTKLN. Diperoleh dari http://setkab.go.id/videoconference-dengan-tki-di-sejumlah-negara-presiden-jokowi-hapus-ktkln/

Sekertariat Migrant Care. (2014). Direktur Eksekutif Migrant Care Raih Penghargaan Yap Thiam Hien Award. Diperoleh dari website: Migrant Care http://migrantcare.net/direktur-eksekutif-migrant-care-raih-penghargaan-yap-thiamhien-award/

Soekanto, S. (2007). Sosiologi Suatu Pengantar. Jakarta, Indonesia: PT. Rajagrafindo Persada.

Sugiyono. (2015). Memahami Penelitian Kualitatif. Bandung, Indonesia: CV. Alfbeta Bandung.

Suhendi, A. (2014, March, 27). Cerita Panjang Satinah dari Mencari Riyal sampai Divonis Hukuman Mati. Diperoleh dari http://www.tribunnews.com/nasional/2014/03/27/cerita-panjang-satinah-dari-mencaririyal-sampai-divonis-hukuman-mati?page $=3$

Syafitri, W. (2012). Determinants of Labour Migration Decisions: The Case of East Java, Indonesia. Hesse, Germany: Kassel University Press GmbH.

Tempo.co. (2014, April, 1). Penggalangan Dana untuk Satinah Tembus Rp 3 Milyar.

Diperoleh dari https://m.tempo.co/read/news/2014/04/01/078566811/penggalangandana-untuk-satinah-tembus-rp-3-miliar

Thomas, C, C. (2010). Empathy in the Global World - An Intercultural Perspective. California, United States of America: SAGE Publications, Inc.

Todaro, H \& T. (19780. Internal Migration in Developing Countries: A Review of Theory, Evidence, Methodology and Research Priorities (International Labour Office). Retrived from http://demografi.bps.go.id/phpfiletree/bahan/kumpulan_tugas_mobilita s_pak_chotib/Kelompok_10/Referensi_paper/Todaro_1980_Internal_ 
Nadya Husein Zainuddin | Public Fundraising Campaign...

Migration_in_Developing_Countries.pdf

Trijono, R. (2015). Metodologi Penelitian Kualitatif. Jakarta, Indonesia: Papas Sinar Sinanti.

Undang-undang Negara Republik Indonesia. (2003). Tenaga Kerja, Buruh dan Pekerja.

United Nations High Commisioner for Human Rights (OHCHR). (2015). Behind Close Doors - Protecting and Promoting The Human Rights of Migrant Domestic Workers in an Irregular Situation. New York, United States and Geneva, Switzerland: United Nations. Diperoleh dari http://www.ohchr.org/Documents/Publications/Behind_closed_doors_HR_PUB_15_4_ EN.pdf

Venus, A. (2009). Manajemen Kampanye Panduan Teoritis dan Praktis dalam Mengefektifkan Kampanye Komunikasi. Bandung, Indonesia: Simbiosa Rekatama Media.

VOA Indonesia. (2015). Pemerintah Akan Hentikan Pengiriman TKI Sektor Informal Secara Bertahap. Diperoleh dari http://www.voaindonesia.com/a/pemerintahakan-hentikan- pengiriman-tki-sektor-informal-secara-bertahap/2657994.html

Wahono. (2015). Bebas dari Hukuman Mati, TKI Satinah Tiba di Tanah Air Hari Ini. Diperoleh dari http://nasional.kompas.com/read/2015/09/02/11595281/Bebasdari.Hukuman.Mati.TKI. Satinah.Tiba.di.Tanah.Air.Hari.Ini

Wulandari, I. (2015). Didakwa Membunuh, Satinah Bebas dari Hukuman Mati di Arab Saudi. Diperoleh dari http://nasional.republika.co.id/berita/nasional/umum/15/09/02/nu1d8n3 46didakwa-membunuh-satinah-bebas-dari-hukuman-mati-di-arab- saudi

Yusuf, A.M. (2014). Metode Penelitian. Jakarta, Indonesia: Prenadamedia Group 